\title{
Odszkodowania z tytułu ustanowienia słu- żebności przesyłu - charakterystyka oraz skutki dla rolników w podatku od towarów i usług oraz podatku dochodowym od osób fizycznych
}

Compensation for the establishment of the easement of transmission - characteristics and effects for farmers in the tax on goods and services and income tax on natural persons

\section{Streszczenie:}

Treść artykułu stanowi zagadnienie skutków podatkowych dla rolników związanych z otrzymanym wynagrodzeniem za ustanowienie służebności przesyłu. Wynagrodzenie to z reguły cechuje się odszkodowawczym charakterem, gdyż rolnik zmuszony jest znosić obecność urządzeń przesyłowych na swoim gruncie, a także korzystanie z niego przez przedsiębiorcę w zakresie wynikającym z umowy czy też orzeczenia sądu. Umożliwienie przedsiębiorcy 
dostępu do instalacji potęguje bowiem dolegliwości związane z pozoru biernym obciążeniem nieruchomości ${ }^{1}$, lecz stanowi szansę na uzyskanie znacznego wynagrodzenia. W zależności od wielu czynników odszkodowanie to może korzystać ze zwolnienia na gruncie podatku od towarów i usług oraz podatku dochodowego od osób fizycznych, jak też - w najgorszym wypadku podlegać opodatkowaniu na gruncie obydwu ustaw. Konsekwencje ekonomiczne w przypadku zwolnienia z opodatkowania są bardzo łatwo dostrzegalne. Zwolnienie z opodatkowania skutkuje pozostawieniem do dyspozycji rolnika większej ilości środków, które może przeznaczyć na dywersyfikację źródeł przychodów, zwiększenie areału lub też unowocześnienie, a tym samym usprawnienie procesu wytwórczego, co również zyskuje bezpośrednie przełożenie na poprawę sytuacji ekonomicznej rolnika.

\section{Abstract:}

The article concerns the question of tax consequences associated with the consideration received for the establishment of transmission easements for farmers. This wages is usually similar to damages, because the farmer is forced to endure the presence of transmission devices on its soil, and its use by the entrepreneur weight range resulting from the contract or the court ruling. Allowing the entrepreneur to access the installation is enhanced, because the symptoms of seemingly passive load of real estate, but a it is also a chance to get a substantial salary. Depending on many factors, compensation may benefit from an exemption on the ground of income tax and value add tax, as well as - in the worst case, may be taxed on the basis of both the statutes. Economic consequences in the event of dismissal of taxation are very easily visible. Exemption from taxation results causes, that farmers are able to make available more resources, which can be used to diversify sources of income, increase of farmlands or modernization, thereby innovating the manufacturing process, which gets a direct impact on improving the situation of farmer economics.

Słowa kluczowe: służebność przesyłu; opodatkowanie rolnicy; skutki podatkowe służebności

Keywords: easement of transmission; taxation of the farmer; tax effects of easement.

1 B. Rakoczy, Służebność przesyłu w praktyce, Warszawa 2012, s. 83. 


\section{Wprowadzenie}

Niejednokrotnie zdarza się, że na gruntach rolnych znajdują się tak zwane urządzenia przesyłowe, czyli instalacje służące do doprowadzania lub odprowadzania płynów, pary, gazu, energii elektrycznej etc. ${ }^{2}$ Ich obecność na cudzym terenie wiąże się z ograniczeniem prawa własności właściciela gruntu. W piśmiennictwie niejednokrotnie rozpatrywano charakter służebności przesyłu, z którą najczęściej należy wiązać obecność tych urządzeń, próbowano sklasyfikować ją jako podtyp szerzej pojmowanej służebności gruntowej bądź też jako osobną kategorię w katalogu ograniczonych praw rzeczowych. Badane zagadnienie, dotyczące kwestii skutków podatkowych ustanowienia służebności przesyłowej na gruntach rolnych, pochodzi z pogranicza prawa cywilnego i prawa podatkowego.

Omawiane zagadnienie należy oceniać przede wszystkim w powiązaniu z rzeczywistością gospodarczą, wiąże się bowiem z doniosłymi skutkami ekonomicznymi dla rolników. Rynek rolniczy jest wymagający, podatny na fluktuacje związane z występowaniem katastrof naturalnych, uzależniony od cen stosowanych na rynkach zagranicznych i podatny na ich wahania. Sam fakt otrzymania dodatkowych środków w postaci odszkodowania znacznie poprawia kondycję finansową rolnika. Pozytywne skutki ekonomiczne stają się jednak tym bardziej dostrzegalne, gdy dodatkowy przychód w postaci wspomnianego wyżej wynagrodzenia będzie cechował się neutralnością podatkową, co niezaprzeczalnie - poprzez zwiększenie puli dostępnych środków - pozwoli na przyśpieszony rozwój oraz poszukiwanie nowych rynków zbytu i unowocześnienie procesu produkcyjnego.

Służebność generalnie ujmowana jest jako obciążenie cudzej nieruchomości, zapewnia uprawnionemu korzyści związane z nieruchomością obciążoną3. Istotnym jest, że służebność przesyłu jest stosun-

2 Art. $49 \S 1$ ustawy z dnia 23 kwietnia 1964 r. Kodeks cywilny (tekst jedn. Dz.U. z 2016 r. poz. 380 ze zm.), dalej: Kodeks cywilny.

3 M. Biernacki, Służebność przesyłu jako ograniczone prawo rzeczowe - kolaż prawniczy, „Rejent” 2010, nr 4 (228), s. 9. 
kowo nową instytucją4. Od pewnego czasu stała się jednak zjawiskiem o bardzo doniosłych skutkach faktycznych i prawnych. W praktyce bowiem stanowi dla zainteresowanych nie tylko uciążliwość, ale także szansę na wysokie odszkodowania dla właścicieli dużych obszarów ziemi. Z oczywistych względów w tej grupie znajdują się głównie rolnicy. Dzięki temu, że polska rzeczywistość gospodarcza cechuje się istotnym stopniem rozdrobnienia gospodarstw rolnych ${ }^{5}$, znaczna część rolników zdążyła doświadczyć uciążliwości związanych z przykładowymi słupami i liniami energetycznymi ustawionymi na ich gruntach. Wiadomym jest bowiem, że za każdym razem, gdy osoba trzecia otrzymuje uprawnienia do działań na nieruchomościach gruntowych, uszczuplenia doznaje konstytucyjnie gwarantowane prawo poszanowania własności.

W doktrynie niewiele jest opracowań poruszających to powszechne zagadnienie, jakim są podatkowe skutki ustanowienia służebności przesyłowej. W niniejszym artykule rozważania te zostają dokonane $\mathrm{z}$ uwzględnieniem konkretnej grupy społecznej, jaką w analizowanym przypadku są rolnicy. Na gruncie przedmiotowego artykułu nastąpi charakterystyka głównych założeń ograniczonego prawa rzeczowego, jakim są służebności przesyłu6, ze szczególnym uwzględnieniem normatywnego charakteru wynagrodzenia za ich ustanowienie. W dalszej kolejności nastąpi prezentacja skutków podatkowych związanych z otrzymanym wynagrodzeniem na gruncie podatku dochodowego od osób fizycznych oraz podatku od towarów i usług, z uwzględnieniem specyfiki typowej dla grupy, jaką są rolnicy.

4 Ustawa z dnia 30 maja 2008 r. o zmianie ustawy - Kodeks cywilny oraz niektórych innych ustaw (Dz.U. Nr 116, poz. 731), zwana dalej: Nowelizacja Kodeksu cywilnego z $2008 \mathrm{r}$.

5 W. Poczta, Gospodarstwa rolne w Polsce na tle gospodarstw Unii Europejskiej. Powszechny spis rolny 2010, Główny Urząd Statystyczny, Warszawa 2013.

6 Charakterystyka ze względu na stopień złożoności, skomplikowania i wieloaspektowości zagadnienia ograniczy się do jego głównych założeń. 
W artykule wykorzystano metodę prawno-dogmatyczną celem zdekodowania norm prawnych, a także prawno-porównawczą oraz analityczną.

\section{Definicja służebności gruntowej}

W celu wyjaśnienia pojęcia służebności przesyłu, koniecznym jest dokonanie opisu szerszego zagadnienia, jakim bez wątpienia jest służebność gruntowa. Zgodnie ze znaczeniem nadanym przez przepisy Kodeksu cywilnego o służebności gruntowej mowa jest w przypadku, gdy nieruchomość zostanie obciążona na rzecz właściciela innej nieruchomości (nieruchomości władnącej) prawem, którego treść polega bądź na tym, że właściciel nieruchomości władnącej może korzystać w oznaczonym zakresie z nieruchomości obciążonej, bądź na tym, że właściciel nieruchomości obciążonej zostaje ograniczony w możności dokonywania w stosunku do niej określonych działań, bądź też na tym, że właścicielowi nieruchomości obciążonej nie wolno wykonywać określonych uprawnień, które mu względem nieruchomości władnącej przysługują na podstawie przepisów o treści i wykonywaniu własności ${ }^{7}$.

Generalizując zaś, służebności są ograniczonymi prawami rzeczowymi na cudzej nieruchomości, które zapewniają uprawnionemu określone korzyści związane z nieruchomością obciążoną8. Utworzone zostać mogą na wiele różnych sposobów - w drodze decyzji administracyjnej, orzeczenia sądowego czy też przez czynność prawną (umowa o ustanowienie służebności). Zauważyć trzeba, że służebność gruntowa może mieć jedynie na celu zwiększenie użyteczności nieruchomości władnącej lub jej oznaczonej części. To właśnie konieczność zwiększenia użyteczności „sąsiedniego” gruntu stanowiła źródło wątpliwości co do ostatecznego charakteru służebności przesyłu.

7 Art. $285 \S 1$ Kodeksu cywilnego.

8 B. Burian, K. Gołębiowski, Komentarz do art. 285 Kodeksu cywilnego, [w:] E. Gniewek, P. Machnikowski (red.), Kodeks cywilny. Komentarz, Legalis, 2016. 


\section{Definicja służebności przesyłu}

Celem zdefiniowania służebności przesyłu wskazać należy na art. $305^{1}$ Kodeksu cywilnego, zgodnie z którym nieruchomość można obciążyć na rzecz przedsiębiorcy, który zamierza wybudować lub którego własność stanowią urządzenia, o których mowa w art. 49 § 1, prawem polegającym na tym, że przedsiębiorca może korzystać w oznaczonym zakresie z nieruchomości obciążonej, zgodnie z przeznaczeniem tych urządzeń (służebność przesyłu).

Istotnym jest wskazanie, że w art. $49 \S 1$, o którym jest mowa w przepisie definiującym służebność przesyłu, wymienione zostały wyjątki od zasady superficies solo cedit ${ }^{9}$, i są to urządzenia służące do doprowadzania lub odprowadzania płynów, pary, gazu, energii elektrycznej oraz inne urządzenia podobne, które na mocy tego przepisu nie należą do części składowych nieruchomości, jeżeli wchodzą w skład przedsiębiorstwa.

Celem zaś ustanowienia służebności przesyłu jest umożliwienie korzystania $\mathrm{w}$ oznaczonym zakresie zgodnie $\mathrm{z}$ przeznaczeniem z urządzeń przesyłowych, tym samym służebność ta zyskuje charakter czynnej. Zastanowić się jednak należy nad ewentualnymi biernymi aspektami tej instytucji, gdyż z oczywistych względów, ze względu na posadowienie stosownych instalacji, niemożliwym jest pełne dysponowanie stosownym fragmentem gruntu. Wydaje się to jednak o tyle wątpliwe, że ze względu na obecność instalacji i tak niemożliwym jest właściwe gospodarowanie na tych odcinkach, tym samym następuje „przymusowe” wyłączenie od upraw ${ }^{10}$. W praktyce ustanowienie służebności przesyłu oznacza pobudowanie/umieszczenie urządzeń elektroenergetycznych na gruntach (zazwyczaj rolnych) w zamian za wynagrodzenie. Inwestor zaś uprawniony jest do wstępu na pole celem usuwania awarii, renowacji urządzeń, ich przebudowy i modernizacji.

$9 \quad$ Art. 48 i art. 191 Kodeksu cywilnego.

10 J. Pokrzywniak, Komentarz do art. $305^{1}$ Kodeksu cywilnego, [w:] M. Gutowski (red.) Kodeks cywilny. Tom I. Komentarz art. 1-44911, 2016, Legalis. 
Odnosząc się do genezy służebności przesyłu, wskazać należy, że przed nowelizacją kodeksu cywilnego z 2008 r. w doktrynie pojawiały się postulaty na temat konieczności uregulowania instytucji, która umożliwiałaby przedsiębiorcom korzystanie z cudzego gruntu w celu budowy i konserwacji urządzeń przesyłowych. Jak wskazuje M. Biernacki, potrzeba była na tyle zauważalna, że w praktyce dochodziło do sytuacji, w których ustanawiano na rzecz przedsiębiorców służebności gruntowe. Dopuszczalność takich działań, mimo poparcia Sądu Najwyższego, budziła $w$ doktrynie wiele wątpliwości ${ }^{11}$. Wprowadzenie do porządku prawnego nowej instytucji było więc dobrze umotywowane i odpowiadało rzeczywistym potrzebom.

Ustanowienie służebności następuje na rzecz przedsiębiorcy będącego właścicielem urządzeń wskazanych w art. $49 \S 1$ Kodeksu cywilnego. Wymogi co do formy zawarcia umowy nie zostały doprecyzowane, przy czym zgodnie z Kodeksem cywilnym oświadczenie właściciela nieruchomości wymaga formy notarialnej.12 Możliwym jest żądanie ustanowienia służebności przesyłowej zarówno przez właściciela, jak i przedsiębiorcę. Dopuszczalne jest również zasiedzenie służebności przesyłu, co jednak znacznie pogarsza sytuację rolnika co do możliwości uzyskania wynagrodzenia.

\section{Odszkodowawczy charakter wynagrodzenia za ustanowienie służebności gruntowej}

Prawo do żądania wynagrodzenia należy do podstawowych uprawnień właściciela nieruchomości obciążonej ${ }^{13}$ i wynika z brzmienia art. $305^{2} \S 1$ i $§ 2$ Kodeksu cywilnego. Zgodnie ze wskazanym przepisem jeżeli właściciel nieruchomości odmawia zawarcia umowy o ustanowienie służebności przesyłu, a jest ona konieczna dla właściwego

\footnotetext{
M. Biernacki, Służebność przesyłu jako..., s. 11.

2 Tamże, s. 20.

13 B. Rakoczy, Służebność przesyłu..., s. 79.
} 
korzystania z urządzeń, o których mowa w art. 49 § 1, przedsiębiorca może żądać jej ustanowienia za odpowiednim wynagrodzeniem.

Analogicznie zostało ukształtowane prawo właściciela nieruchomości do żądania ustanowienia służebności w przypadku, gdy to przedsiębiorca odmawia zawarcia umowy. W dyskusji na temat odszkodowawczego charakteru wspomnianego wynagrodzenia za ustanowienie służebności gruntowej zajął stanowisko również Naczelny Sąd Administracyjny. W orzeczeniu o sygnaturze II FSK 654/10 z dnia 29 września 2011 r. wskazał, że wynagrodzenie bez wątpienia ze względu na swoje cechy spełnia rolę odszkodowania. Jest to niezwykle cenny pogląd z uwagi na fakt, że możliwym stało się zakwalifikowanie wynagrodzenia do grona odszkodowań z tytułu służebności, a tym samym dochodzenie jego zwolnienia od opodatkowania podatkiem dochodowym od osób fizycznych. NSA we wskazanym wyroku uznał: „Przez odszkodowanie wypłacone z tytułu ustanowienia służebności gruntowej rozumieć należy świadczenie pieniężne (wynagrodzenie) otrzymane przez osobę fizyczną będącą posiadaczem gruntów wchodzących w skład gospodarstwa rolnego, stanowiące odszkodowanie, czyli rekompensatę (ekwiwalent) za ograniczenie swojego prawa własności takich gruntów na rzecz przedsiębiorcy realizującego inwestycję liniową. Niewątpliwie bowiem takie wynagrodzenie stanowi odszkodowanie (ustalane szacunkowo, „z góry”) za szkody, jakie poniesie posiadacz gruntów rolnych wskutek realizacji takiej inwestycji, w szczególności za utracone korzyści (lucrum cessans)"14.

\section{Wysokość wynagrodzenia}

Przedsiębiorcy zgłaszali propozycje, by zawrzeć w regulacji kodeksowej szczegółowe zasady obliczania wynagrodzenia za korzystanie ze służebności przesyłowej. Podobny postulat sformułował B. Rako-

14 Wyrok NSA z dnia 29 września 2011 r., II FSK 654/10, CBOSA. 
czy: istotnym uchybieniem legislacyjnym jest także to, że $w$ Kodeksie cywilnym wcale nie przyjęto rozwiq̨zania polegajacego na obligatoryjnym określeniu wynagrodzenia, poza sytuacja, gdy służebność ustanawiana jest przez sq̨d15. Postulaty te, prawdopodobnie ze względu na mnogość poszczególnych stanów faktycznych oraz - zdaje się - swobodę zawierania umów, nie zostały zrealizowane. Wydaje się, że właściwym byłoby sformułowanie ustawowego wymogu każdorazowego sporządzania operatu szacunkowego celem wyceny tego prawa. Z pewnością byłaby to pewna gwarancja dla właścicieli gruntów, lecz nie wolno zapominać, że możliwym jest również ustanowienie służebności przesyłu bez wynagrodzenia.

\section{Skutki w podatku dochodowym od osób fizycznych odszkodowania otrzymanego z tytułu służebności przesyłowej}

Dochody rolników ze sprzedaży produktów rolnych w przeważającej ilości przypadków są zwolnione $\mathrm{z}$ opodatkowania podatkiem dochodowym od osób fizycznych. Różnica między opodatkowaniem podatkiem dochodowym od osób fizycznych rolników a osobami czerpiącymi dochody z innych źródeł zaciera się, gdy mowa jest o wynagrodzeniu za ustanowienie służebności przesyłu. Ustawa bowiem $\mathrm{w}$ tej kwestii nie różnicuje skutków podatkowych w zależności od zajęcia właściciela czy też rodzaju gruntu obciążonego służebnością. Kluczowym wyrokiem w kwestii opodatkowania odszkodowań otrzymanych z tytułu ustanowienia służebności gruntowej podatkiem dochodowym od osób fizycznych jest wspomniane już wcześniej orzeczenie Naczelnego Sądu Administracyjnego z dnia 29 września 2011 r. o sygnaturze II FSK 654/10, rozstrzygające kwestie indywidualnej interpretacji podatkowej, w której to organy odmówiły prawa do zwolnienia wynagrodzenia za ustanowienie służebności przesyłu z odszko-

15 B. Rakoczy, Służebność przesyłu..., s. 81. 
dowania. 0 złożoności zagadnienia świadczy fakt, że sprawa musiała dotrzeć aż do Naczelnego Sądu Administracyjnego, by otrzymać korzystne dla podatnika rozstrzygnięcie. Wprawdzie w polskim porządku prawnym nie ma powszechnej zasady związania sądów orzeczeniami, jednak argumentacja i rozstrzygnięcie autorytetu stanowi dla praktyków mocny oręż $\mathrm{w}$ walce $\mathrm{z}$ organami, szczególnie gdy mowa jest o orzeczeniu Sądu Najwyższego czy też Naczelnego Sadu Administracyjnego. Zauważalnym jest również, że w istocie orzeczenia NSA wywierają ogromny wpływ na dalszą praktykę orzeczniczą.

Kluczowym przepisem, którego interpretacja legła u podstaw wskazanego rozstrzygnięcia, jest artykuł art. 21 ust. 1 pkt 120 lit. a ustawy z dnia 26.07.1991 r. o podatku dochodowym od osób fizycznych ${ }^{16}$. Całość rozważań na temat możliwości zwolnienia z opodatkowania odszkodowania otrzymanego z tytułu ustanowienia służebności przesyłu sprowadzała się do odpowiedzi na pytanie, czy służebność przesyłu jest rodzajem służebności gruntowej, czy też stanowi inne, niezależne prawo. $W$ tym celu nie wystarcza już wykładnia literalna, oprzeć się należy na wykładni systemowej zewnętrznej i celowościowej.

Zdaniem zainteresowanej wydaniem interpretacji, której analiza legła u podstaw cytowanego orzeczenia, przedmiotowe odszkodowanie dla posiadaczy gruntów wchodzących w skład gospodarstwa rolnego powinno korzystać ze zwolnienia z podatku od osób fizycznych, gdyż służebność przesyłu jest rodzajem służebności gruntowej, która korzysta z takiego zwolnienia. Organ podatkowy, nie zgadzając się z tym stanowiskiem, wskazał na literalne i celowościowe znaczenie art. 9 pkt 1 u.p.d.o.f., który bardzo ogólnie opisuje przedmiot opodatkowania: „opodatkowaniu podatkiem dochodowym podlegają wszelkiego rodzaju dochody, z wyjątkiem dochodów wymienionych w art. $21,52,52$ a i 52c oraz dochodów, od których na podstawie przepisów Ordynacji podatkowej zaniechano poboru podatku". Przepis ten konstytuuje zasadę powszechności opodatkowania, co w skrócie oznacza

16 Tekst jedn. Dz.U. z 2016 r., poz. 2032 ze zm., dalej: u.p.d.o.f. 
znaczne utrudnienie w kwestii dowodzenia zasadności zwolnienia $\mathrm{z}$ opodatkowania $\mathrm{w}$ przypadku, gdy takie zwolnienie nie wynika wprost z wykładni literalnej przepisu. Jest to związane z ogólną dyrektywą postępowania, by wszelkie wyjątki od zasady powszechności opodatkowania interpretować ściśle.

Wątpliwości pojawiły się w dyskusji, czy zamiarem ustawodawcy było rozszerzenie katalogu zwolnień poprzez doregulowanie w kodeksie cywilnym służebności przesyłowej. Służebność przesyłu, jako niewymieniona wprost w cytowanym wcześniej przepisie, nie została przez organ zwolniona $\mathrm{z}$ opodatkowania i takie postrzeganie tego zagadnienia mogłoby znaleźć oparcie $\mathrm{w}$ art. 84 Konstytucji RP17, zgodnie z którym każdy jest obowiązany do ponoszenia ciężarów i świadczeń publicznych, w tym podatków, określonych w ustawie. Również Wojewódzki Sąd Administracyjny w Szczecinie nie zgodził się z zasadnością zwolnienia odszkodowania z opodatkowania, podtrzymując stanowisko organu. W uzasadnieniu wskazał, że warunkiem zwolnienia wypłaconego odszkodowania na mocy art. 21 ust. 1 pkt 120 u.p.d.o.f. jest to, aby prawo do tego odszkodowania wynikało z tytułu ustanowienia służebności gruntowej, z tytułu rekultywacji gruntów albo z tytułu szkód powstałych w uprawach rolnych i drzewostanie ${ }^{18}$.

Pozytywnego zakończenia sprawy skarżąca rolniczka doczekała się w orzeczeniu Naczelnego Sądu Administracyjnego, w którym to Sąd zwrócił uwagę na zmianę przepisów Kodeksu cywilnego, które weszły w życie z dniem 3 sierpnia 2008 r. ${ }^{19}$ Sięgając do uzasadnienia wskazanej powyżej nowelizacji, szczególną uwagę poświęcić należy spostrzeżeniom: „służebność przesyłu jest odmianą służebności gruntowej". W art. $285 \S 2$ k.c. ustawodawca - regulując służebność gruntową - wyraźnie wskazał, że jedynym celem ustanowienia tej służeb-

17 Konstytucja Rzeczypospolitej Polskiej z dnia 2 kwietnia 1997 r. (Dz.U. Nr 78, poz. 483 ze zm.).

18 Wyrok NSA z dnia 29 września 2011 r., II FSK 654/10, CBOSA.

19 Nowelizacja Kodeksu cywilnego z 2008 r., projekt zmian wraz z uzasadnieniem: http://www.sejm.gov.pl. 
ności jest zwiększenie użyteczności nieruchomości władnącej lub jej oznaczonej części. Takie określenie celu służebności przesyłu nie jest możliwe, gdyż nie występuje tu nieruchomość władnąca. Służebność przesyłu ustanawia się na rzecz przedsiębiorcy (art. $305^{1}$ k.c.). Uzasadnione jest więc przyjęcie, że jedynym celem ustanowienia służebności przesyłu jest zwiększenie użyteczności przedsiębiorstwa (art. $305^{1} \S 2$ k.c.)".

Jest to bardzo korzystne stanowisko dla domagających się odszkodowania. Co więcej, ustawodawca w art. $305^{4}$ wprost nakazuje, by do służebności przesyłu stosować odpowiednio przepisy o służebnościach gruntowych. Przemawiają za tym względy celowościowe, wykładnia systemowa zewnętrzna oraz historyczna.

\section{Skutki w podatku od towarów i usług odszkodowania otrzymanego z tytułu służebności przesyłowej}

Zgodnie z art. 2 pkt 19 ustawy o VAT, za rolnika ryczałtowego uznaje się rolnika dokonującego dostawy produktów rolnych pochodzących z własnej działalności rolniczej lub świadczącego usługi rolnicze, korzystającego ze zwolnienia od podatku na podstawie art. 43 ust. 1 pkt 3 , z wyjątkiem rolnika obowiązanego na podstawie odrębnych przepisów do prowadzenia ksiąg rachunkowych.

Z kolei zwolnienie, o którym mowa w przepisie, dotyczy dostawy produktów rolnych pochodzących z własnej działalności rolniczej dokonywanej przez rolnika ryczałtowego oraz świadczenia usług rolniczych przez rolnika ryczałtowego. Z przepisów tych wynika, że rolnicy są w większości przypadków zwolnieni z obowiązków nakładanych ustawą o podatku od towarów i usług. Zwolnienia tego nie należy jednak generalizować. Może się bowiem okazać, że rolnicy prowadzący działalność nie mieszczącą się w zakresie wskazanego zwolnienia będą musieli uiścić należny podatek. Niejednokrotnie bowiem zdarza się, że rolnicy świadczą różnego rodzaju usługi niezwią- 
zane z tak pojmowanym rolnictwem. Przykładem może być usługa polegająca na sprzedaży butli z gazem lub też, jak się okazuje, oferowaniu gruntów do wykonywania działalności gospodarczej. Tak jest również w przypadku służebności przesyłu. W tym celu należy przeanalizować definicję działalności gospodarczej zawartą w art. 15 ust 2 ustawy o podatku od towarów i usług ${ }^{20}$, zgodnie z którą działalność gospodarcza obejmuje wszelką działalność producentów, handlowców lub usługodawców, w tym podmiotów pozyskujących zasoby naturalne oraz rolników, a także działalność osób wykonujących wolne zawody. Działalność gospodarcza obejmuje w szczególności czynności polegające na wykorzystywaniu towarów lub wartości niematerialnych i prawnych $\mathrm{w}$ sposób ciągły dla celów zarobkowych. W pierwszym zdaniu definicji jako jeden z podmiotów wskazani zostali rolnicy, natomiast grunty mogą stanowić towar w rozumieniu przepisów niniejszej ustawy. Tym samym rolnik, godząc się na ustanowienie służebności za wynagrodzeniem, świadczy usługi w rozumieniu przepisów ustawy o VAT, a więc powinien opodatkować uzyskane z tego tytułu przychody według podstawowej stawki VAT, wynoszącej obecnie 23\%. Dobrą wiadomością jest jednak fakt, że rolnik może skorzystać ze zwolnienia podmiotowego ${ }^{21}$ i jeśli spełnione zostaną określone warunki, nie będzie koniecznym uiszczenie należnego podatku VAT. Jest to ściśle uzależnione od konfiguracji opodatkowania, którą wybierze - przykładowo rolnik ryczałtowy, który prowadzi pozarolniczą działalność gospodarczą, nie będzie mógł skorzystać ze zwolnienia, usługa będzie opodatkowana. Jednak rolnik ryczałtowy nieprowadzący pozarolniczej działalności gospodarczej będzie uprawniony do skorzystania z ulgi.

20 Ustawa z dnia 11 marca 2004 r. o podatku od towarów i usług, (tekst jedn. Dz.U. z 2016 r., poz. 710 ze zm.), dalej: ustawa o VAT.

21 Art. 113 ust 1 ustawy o VAT. 


\section{Podsumowanie}

Z zaprezentowanych w artykule rozważań wynika, że w zależności od ukształtowania stosunku łączącego przedsiębiorcę z rolnikiem przychody uzyskane z tytułu wynagrodzenia za ustanowienie służebności przesyłowej mogą być neutralne podatkowe (zakładając, że rolnik będzie uprawniony do skorzystania ze zwolnienia podmiotowego na gruncie podatku VAT, a wynagrodzeniu za ustanowienie służebności przesyłu zostanie nadany charakter odszkodowawczy). Jednak przy skrajnie niekorzystnym ukształtowaniu umowy, gdy wynagrodzenie nie przyjmie postaci odszkodowania, lecz szeroko rozumianego „wynagrodzenia”, przy jednoczesnym prowadzeniu przez rolnika ryczałtowego pozarolniczej działalności gospodarczej, rolnik będzie zobowiązany opodatkować podatkiem dochodowym od osób fizycznych przychód otrzymany z tytułu ustanowionej służebności, natomiast z tytułu usługi zobowiązany będzie wystawić fakturę VAT i uiścić należny podatek od towarów i usług. Kompleksowe ujęcie sytuacji podatkowej rolników na gruncie podatku od towarów i usług i podatku dochodowego od osób fizycznych pozwala na zróżnicowanie skutków podatkowych oraz generalne stwierdzenie, że w zależności od stopnia dbałości o swoje obowiązki fiskalne, rolnik może być zwolniony z zobowiązań podatkowych związanych $\mathrm{z}$ opodatkowaniem wynagrodzenia z tytułu ustanowienia służebności przesyłu, lub też, w najmniej korzystnej sytuacji, podlegać opodatkowaniu na gruncie obydwu ustaw.

\section{Literatura:}

Biernacki M., Służebność przesyłu jako ograniczone prawo rzeczowe - kolaż prawniczy, „Rejent, Miesięcznik notariatu polskiego”, 2010, nr 4 (228).

Burian B., Gołębiowski K., „Komentarz do art. 285 Kodeksu cywilnego”, [w:] E. Gniewek, P. Machnikowski (red.) Kodeks cywilny. Komentarz, Legalis, 2016.

Dzwonkowski H., Ordynacja podatkowa. Komentarz, Legalis 2016. 
Lewandowski P., Służebność przesyłu w prawie polskim, Warszawa 2014.

Michalik T., Komentarz do ustawy o VAT, Warszawa 2016 r.

Poczta W., Gospodarstwa rolne w Polsce na tle gospodarstw Unii Europejskiej,

Powszechny spis rolny 2010, Główny Urząd Statystyczny, Warszawa 2013.

Rakoczy B., Służebność przesyłu w praktyce, LexisNexis, Warszawa 2012.

Zubrzycki J., Leksykon VAT, Unimex. Wrocław, 2015 